\title{
Intensi Pembelian Produk Ramah Lingkungan Berdasar Theory of Planned Behaviour
}

\author{
Bernadetta Diansepti Maharani*, Lusia Tria Hatmanti Hutami, Kadek Isna \\ Fakultas Ekonomi, Universitas Sarjanawiyata Tamansiswa Yogyakarta, \\ Yogyakarta, Indonesia \\ *bernadettadian@ustjogja.ac.id
}

\begin{abstract}
This study explains one of the phenomena in Marketing Management, namely the purchasing intention of green products in generation Z. This study uses a modification of the theory development of Theory of Planned Behavior. The purpose of this study was to analyze the effect of attitudes, subjective norms, perceived behavioral control and environmental concern on the purchasing intention of green products in generation Z. The research method used Smart PLS. This study uses a purposive convenience sampling method on 150 college students and students in Yogyakarta who were born between 1995-2012 and know about green products. The research findings indicate that attitudes, subjective norms, perceived behavioral control and environmental concern positively effect on the purchasing intention of green products in generation $Z$.
\end{abstract}

Keywords: Attitude, Environmental Concern, Subjective Norm, Perceived Behavioral Control, Purchasing Intention

\section{PENDAHULUAN}

Salah satu isu terbesar dunia saat ini yaitu isu lingkungan seperti perubahan iklim, semakin meningkatnya polusi udara, populasi manusia yang terlalu besar, dan sebagainya. Di Indonesia isu-isu tentang lingkungan sangat meluas akhir-akhir ini, berbagai fenomena alam yang dipengaruhi oleh permasalahan lingkungan seperti rusaknya terumbu karang, sampah plastik yang semakin banyak, polusi udara serta deforestasi. Isu-isu lingkungan tersebut merebak karena di Indonesia terjadi pencemaran lingkungan yang disebabkan semakin banyaknya industri yang kurang peduli dengan lingkungan, semakin banyaknya pertumbuhan penduduk dan semakin banyaknya sumber daya alam yang tidak diperbaharui yang digunakan. Isu lingkungan menjadi sangatlah penting diperhatikan karena kualitas lingkungan yang akan berpengaruh pada kualitas kehidupan manusia saat ini serta di masa depan. Adanya isu lingkungan yang semakin merebak juga menjadi fenomena tentang green consumer behaviour yang menjadikan sebuah paradigma baru bagi penelitian dibidang pemasaran (Jaiswal \& Kant, 2018). Beberapa penelitian telah membuktikan bahwa dijelaskan faktor-faktor yang mampu mempengaruhi jumlah pembelian produk ramah lingkungan. Dalam penelitian Varah, Mahongnao, Pani, dan Khamrang (2020) menyatakan ada 5 faktor yang mempengaruhi intensi pembelian green products seperti sikap, norma subjektif keinginan pelanggan berbelanja produk, keinginan dari konsumen dalam berbelanja produk premium dan perhatian terhadap lingkungan. Dalam penelitian tersebut memaparkan bahwa kelima faktor tersebut mempengaruhi intensi pembelian konsumen 
muda, dengan adanya populasi generasi muda yang besar ini akan berpengaruh pula terhadap niat berbelanja produk ramah lingkungan. Pada penelitian ini, menggunakan modifikasi Theory Planned of Behaviour (TPB) yang dinyatakan oleh Ajzen (1991) serta menambahkan kepedulian lingkungan (environmental concern). Penelitian ini menganalisis pengaruh dari sikap (attitude), norma subjektif (subjective norm), kontrol perilaku (perceived behavioral control) serta kepedulian lingkungan (environmental concern) terhadap niat berbelanja produk ramah lingkungan pada generasi Z. Sikap dapat diartikan sebagai evaluasi keseluruhan dari perilaku pribadi yang dipandang sebagai evaluasi dalam pembelian serta dapat memprediksi tindakan konsumen dalam pembelian produk (Sun \& Wang, 2019). Norma subjektif merupakan pendapat orang lain yang penting bagi seseorang dan mempunyai pengaruh dalam pengambilan keputusan pembelian (Yadav \& Pathak, 2016). Kontrol perilaku merupakan perasaan yang mengarah pada kemudahan ataupun kesulitan yang dirasakan oleh konsumen dalam melakukan pembelian (Ajzen, 2012). Kepedulian lingkungan mengacu pada sejauh mana seseorang menyadari dan mendukung untuk mengatasi berbagai masalah lingkungan serta menunjukkan kesediaan untuk berkontribusi untuk mencari solusi dari permasalahan lingkungan yang terjadi (Varah, et al., 2020). Pada penelitian ini konsumen muda yaitu generasi $\mathrm{Z}$ yang lahir diantara 1995-2012 yang merupakan populasi terbesar saat ini (Noor, et al., 2017). Para konsumen muda juga mempunyai keprihatinan tentang dampak dimasa depan dari tindakan mereka saat ini, karena mereka harus menghabiskan waktu yang panjang dengan kondisi lingkungan semakin hari semakin memburuk (Yadav \& Pathak, 2016). Konsumen muda juga dapat dianggap sebagai titik awal untuk merasionalisasikan dilema tentang lingkungan yang sedang dihadapi dunia masa kini. Selain itu konsumen muda merupakan golongan konsumen yang paling berpengaruh untuk berbelanja produk ramah lingkungan karena mereka memiliki sikap yang fleksibel, mempunyai pengetahuan yang terbuka serta mempunyai kesadaran tentang lingkungan (Varah, et al., 2020). Generasi Z mempunyai keinginan untuk mengonsusmsi produkproduk ramah lingkungan karena dengan adanya teknologi mereka dapat dengan mudah mendapatkan informasi tentang dampak pencemaran lingkungan, dengan hal itu mereka mempunyai pengetahuan tentang pelestarian alam, isu-isu ramah lingkungan dan memiliki kesadaran yang tinggi akan isu lingkungan (Prayoga, Adiyadnya, \& Putra, 2020). Berdasarkan beberapa hasil penelitian bahwa konsumen muda yang merupakan generasi $\mathrm{Z}$ merupakan kelompok konsumen yang mempunyai pendidikan tinggi, hal ini diharapkan mereka dapat memberikan dampak positif bagi lingkungannya.

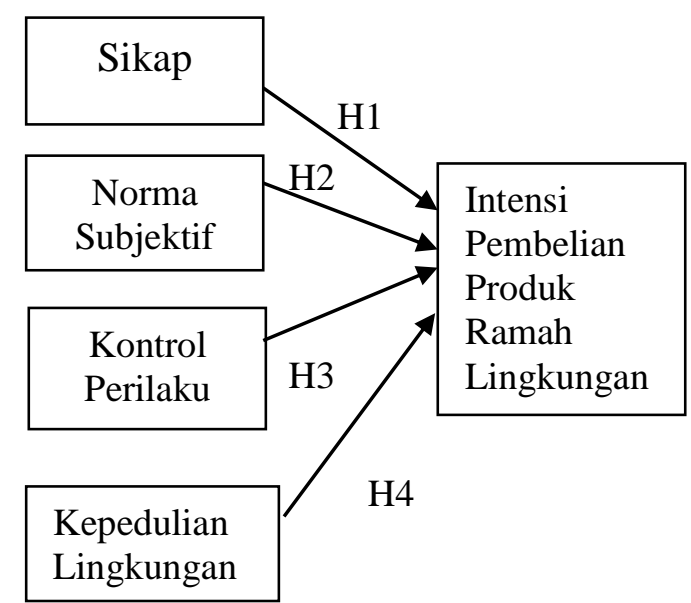

Gambar 1. Kerangka Konsep Model Penelitian

Sumber: kerangka konsep model penelitian yang diadaptasi dari penelitian Shukla, (2019)

Sikap mengacu pada individu untuk membentuk tingkah laku, tingkah laku tersebut bisa positif ataupun negatif. Sikap seorang individu merupakan suatu penilaian terhadap hasil perilaku baik atau buruk dan keinginan untuk melakukan sesuatu atau tidak (Varah et al., 2020). Sikap merupakan evaluasi dari perilaku pribadi (Ajzen, 1991). Sikap juga dapat dipandang sebagai salah satu evaluasi berbelanja produk ramah lingkungan serta dapat memprediksi tingkah laku berbelanja produk ramah lingkungan (Sun \& Wang, 2019). Pengaruh sikap 
terhadap niat berbelanja produk ramah lingkungan mempunyai hubungan positif dalam berbagai studi dari beberapa negara di berbagai jenis produk ramah lingkungan salah satu contohnya yaitu produk makanan organik (Chaudhary \& Bisai, 2018). Dalam kegiaatan berbelanja produk ramah lingkungan yang menjadi dimensi terpenting dalam penelitian green marketing yaitu sikap konsumen (Noor, et al., 2017).

Menurut Ajzen (1991) norma subjektif merupakan pemahaman tentang persepsi individu berperilaku dalam kondisi tertentu yang mengikuti pendapat orang lain. Norma subjektif merupakan perhatian terhadap perasaan yang bersumber dari tekanan sosial yang berasal dari perasaan seseorang (Varah, et al., 2020). Dengan demikian, dengan adanya pengaruh dari orang lain dapat meningkatkan niat berbelanja seseorang untuk berbelanja produk ramah lingkungan. Menurut penelitian yang sebelumnya telah dilakukan oleh Sun dan Wang (2019) menyatakan bahwa norma subjektif secara positif berdampak pada niat konsumen dalam berbelanja produk ramah lingkungan di China. Bersumber pada penelitian dari Nguyen dan Nguyen (2021) menyatakan adanya pengaruh positif norma subjektif terhadap niat beli dikalangan milenial di Vietnam. Menurut hasil penelitian dari (Noor, et al., 2017) menyatakan bahwa norma subjektif secara signifikan dapat menjelaskan niat berbelanja produk ramah lingkungan pada Generasi Z di Malaysia.

Kontrol perilaku dapat dirasakan oleh seseorang yang mengacu terhadap kesederhanaan ataupun kesukaran yang dirasakan seseorang dalam melakukan sesuatu (Ajzen, 1991). Menurut Sun dan Wang, (2019) pada saat seseorang berbelanja produk ramah lingkungan mungkin ada beberapa faktor eksternal seperti waktu, harga, pengetahuan dan keterampilan. Pada saat seseorang percaya serta memiki lebih banyak sumber daya, peluang dan mengharapkan sedikit hambatan, oleh karena itu mereka merasakan kontrol perilaku yang lebih kuat dan intensi untuk berbelanja produk ramah lingkungan akan lebih besar pula. Menurut Shukla (2019), penelitian yang telah dilakukan pada generasi muda di India menyatakan bahwa kontrol perilaku mempunyai dampak positif dan signifikan terhadap intensi berbelanja produk ramah lingkungan. Menurut hasil penelitian dari Sun dan Wang (2019) yang menyatakan bahwa intensi pembelian konsumen di Cina dipengaruhi oleh kontrol perilaku.

Kepedulian lingkungan selalu dikaitkan dengan kepedulian seseorang terhadap masalah lingkungan, dapat juga ditekankan sebagai salah satu kesatuan yang utama untuk memprediksi perilaku seseorang terhadap produk ramah lingkungan (Jaiswal \& Kant, 2018). Dengan demikian jika seseorang mempunyai kepedulian lingkungan yang tinggi, intensi pembelian produk ramah lingkungan akan juga semakin tinggi. Seorang konsumen yang peduli dengan masalah lingkungan, bersikap positif untuk berbelanja produk ramah lingkungan dan mempunyai motivasi yang tinggi untuk berbelanja produk ramah lingkungan untuk menjaga pola gaya hidup sehat (Nekmahmud $\&$ Fekete-Farkas, 2020). Berdasarkan hasil penelitian dari Lee (2008) yang dilakukan pada konsumen di Hongkong menyatakan bahwa kepedulian lingkungan berpengaruh positif dan signifikan pada intensi pembelian produk ramah lingkungan. Pada penelitian tersebut menyatakan juga bahwa kepedulian lingkungan merupakan faktor terbesar kedua yang mempengaruhi niat berbelanja produk ramah lingkungan. Menurut penelitian dari Shukla (2019) menyatakan bahwa kepedulian terhadap lingkungan sekitar terhadap intensi pembelian produk rampak positif pada pembelanjaan produk ramah lingkungan pada generasi milenial di India.

$\mathrm{H}_{1}$ : Sikap berpengaruh positif terhadap intensi pembelian produk ramah lingkungan.

$\mathrm{H}_{2}$ : Norma subjektif berpengaruh positif terhadap intensi produk ramah lingkungan.

$\mathrm{H}_{3}$ : Kontrol perilaku berpengaruh positif terhadap intensi pembelian produk ramah lingkungan. 
$\mathrm{H}_{4}$ : Kepedulian lingkungan berpengaruh positif terhadap intensi pembelian produk ramah lingkungan

\section{METODE}

Peneltian ini bersifat kuantitatif yang menggunakan pendekatan explanatory research mencoba membangun hipotesis dari rumusan masalah dan menjawabnya berdasarkan analisis data yang bersumber dari kuesioner. Populasi penelitian ini yaitu mahasiswa danatau siswa yang ada di Yogyakarta. Menurut Sugiyono (2010) sampel merupakan elemen dari jumlah danatau karakteristik yang dimiliki oleh populasi. Sampel adalah obyek yang sesungguhnya dari penelitian tersebut. Sampel dalam penelitian ini yaitu mahasiswa danatau siswa di Yogyakarta yang masuk kedalam generasi Z lahir antara 1995-2012. Menurut Hair, Sarstedt, Ringle, dan Mena (2012) penentuan jumlah sampel yaitu jumlah indikator dikali 5 sampai 10. Pada penelitian ini sampel yang digunakan sebanyak 150 responden, diperoleh dari 21 (indikator) x 7 yaitu sebesar 147, yang kemudian dibulatkan keatas menjadi 150 responden. Metode pengambilan sampel yang digunakan yaitu metode purposive sampling yaitu pengambilan sampel berdasarkan ciri-ciri tertentu yaitu mahasiswa dan siswa di Yogyakarta yang lahir diantara tahun 1995-2012 dan mengetahui tentang green product. Metode penelitian ini menggunakan analisis jalur untuk menguraikan faktor-faktor yang digunakan dalam penelitian dengan aplikasi Smart PLS. Sebelum analisis jalur dijalankan, peneliti menguji model pengukuran dan model struktural untuk memastikan sudah tercapai prasyarat yang diperlukan. Analisis jalur berarti variasi dari analisis regresi berganda dan berguna untuk menganalisis sejumlah masalah yang terlibat dalam sebab-akibat (Stage, Carter \& Nora, 2004). Semua kuesioner menggunakan lima skala likert. Item kuesioner berisi sikap (attitude), norma subjektif (subjective norm), kepedulian lingkungan (environmental concern), intensi pembelian produk ramah lingkungan (green product purchasing intention) diadaptasi dari Shukla (2019). Hipotesis diterima bila nilai signifikansi $p$ value $<0,05$.

\section{HASIL DAN PEMBAHASAN}

Penyebaran kuesioner pada penelitian ini ditujukan kepada mahasiswa dan siswa SMA di Yogyakarta yang masuk ke dalam generasi Z lahir antara 1995-2012 dengan sampel berjumlah 150 responden. Berdasarkan proporsi responden penelitian dari perspektif gender terdiri dari responden laki-laki sebesar $31,33 \%$ dan responden perempuan sebesar $68,67 \%$. Apabila ditinjau dari persebaran tahun lahir yang termasuk dalam kategori generasi $\mathrm{Z}$ dengan dominasi responden berada pada rentang tahun lahir 2001-2003 sebanyak 46,67\%, responden dengan rentang tahun lahir 1998-2000 sebesar 41,33\%, responden dengan rentang tahun lahir 1995-1997 sebesar 7,33\% dan responden dengan rentang tahun lahir di atas 2004 sebesar 4,67\%. Sedangkan jika dilihat dari jumlah uang saku yang dimiliki responden sebagian besar sampel yang diambil memperoleh uang saku lebih dari Rp1.500.000 adalah sebesar 60,67\%, responden dengan uang saku Rp500.000Rp1.000.000 sebesar 30,67\%, responden dengan uang saku Rp1.000.000-Rp1.500.000 sebesar $8,67 \%$ dan responden dengan uang saku kurang dari Rp500.000 sebesar 0\%. Sehingga hal ini mengkonfirmasi data karakteristik sebaran responden termasuk ke dalam kategori generasi $\mathrm{Z}$.

\section{Tabel 1. Uji Reliabilitas Konstruk}

\begin{tabular}{lcr}
\hline & $\begin{array}{c}\text { Cronbach's } \\
\text { Alpha }\end{array}$ & $\begin{array}{r}\text { Reliabilitas } \\
\text { Komposit }\end{array}$ \\
\hline $\begin{array}{l}\text { Attitude } \\
\begin{array}{l}\text { Subjective Norm } \\
\text { Perceived }\end{array}\end{array}$ & 0,764 & 0,849 \\
$\begin{array}{l}\text { Behavioral } \\
\begin{array}{l}\text { Control } \\
\text { Enviromental }\end{array}\end{array}$ & 0,753 & 0,848 \\
$\begin{array}{l}\text { Concern } \\
\text { Green Product }\end{array}$ & 0,798 & 0,846 \\
$\begin{array}{l}\text { Purchasing } \\
\text { Intention }\end{array}$ & & 0,861 \\
\hline
\end{tabular}


Reliabilitas berarti bahwa parameter kestabilan internal dari indikator suatu variabel bentukan yang menerangkan derajat sejauh mana masing-masing indikator mengindikasikan sebuah variabel bentukan yang umum (Haryono, 2016). Hasil Tabel 1. Uji Reliabilitas Konstruk menunjukkan bahwa berdasarkan indikator Cronbach's Alpha semua variabel dalam penelitian ini sudah lolos kriteria $(>0,70)$. Hasil dari pengujian reliabilitas komposit menunjukkan bahwa nilai indikator lebih besar dari 0,70. Berdasarkan kedua hasil tersebut, dapat disimpulkan bahwa indikator konstruk penelitian konsisten dengan pengukurannya.

Tabel 2. Uji Validitas Konvergen

\begin{tabular}{lc}
\hline & AVE \\
\hline Attitude & 0,586 \\
Subjective Norm & 0,587 \\
Perceived Behavioral Control & 0,578 \\
Enviromental Concern & 0,556 \\
Green Product Purchasing Intention & 0,658 \\
\hline
\end{tabular}

Validitas konvergen berarti bahwa seperangkat indikator mencerminkan satu variabel laten dan yang mendasari variabel laten tersebut. Salah satu cara mengujinya adalah dengan menggunakan AVE lebih besar 0,50 (Garson, 2016). Hasil dari Tabel 2. Uji Validitas Konvergen menunjukkan bahwa nilai Average Variance Extracted $(\mathrm{AVE})>0,50$ pada semua indikator. Hal tersebut berarti satu variabel laten mampu menerangkan lebih dari setengah varian di rata-rata indikatornya. Hasil ini menegaskan bahwa validitas konvergen dalam penelitian ini cukup baik.

Tabel 3. Kriteria Fornell-Larcker

\begin{tabular}{lccccc}
\hline & $A$ & $E C$ & $P B$ & $P I$ & $S N$ \\
\hline$A$ & 0,765 & & & & \\
$E C$ & 0,509 & 0,745 & & & \\
$P B$ & 0,532 & 0,508 & 0,761 & & \\
$P I$ & 0,605 & 0,583 & 0,573 & 0,811 & \\
$S N$ & 0,431 & 0,392 & 0,540 & 0,565 & 0,766 \\
\hline
\end{tabular}

Discriminant Validity mengukur sampai seberapa jauh suatu komposisi benarbenar berbeda dari komposisi lainnya
(Haryono, 2016), salah satu cara mengukurnya adalah dengan Uji FornellLarcker. Postulat Fornell-Larcker menyatakan bahwa suatu variabel laten berbagi varian lebih dengan indikator yang mendasarinya daripada dengan variabel-variabel laten lainnya (Fornell \& Larcker, 1981). Berdasarkan Tabel 3 Kriteria Fornell-Larcker menunjukkan bahwa nilai AVE setiap variabel lebih tinggi dari $R^{2}$ variabel lainnya, yang berarti uji validitas diskriminan penelitian ini sudah baik.

Tabel 4. Rasio Heterotrait-Monotrait (HTMT)

\begin{tabular}{lccccc}
\hline & $A$ & $E C$ & $P B$ & $P I$ & $S N$ \\
\hline$A$ & & & & & \\
$E C$ & 0,652 & & & & \\
$P B$ & 0,688 & 0,644 & & & \\
$P I$ & 0,758 & 0,713 & 0,716 & & \\
$S N$ & 0,566 & 0,503 & 0,716 & 0,715 & \\
\hline
\end{tabular}

Rasio Heterotrait-Monotrait (HTMT) berarti bahwa rata-rata geometrik dari korelasi heterotrait-hetermethod (yaitu korelasi indikator di seluruh pengukuran konstruksi yang berbeda) dibagi dengan rata-rata dari monotrait-hetermethod korelasi (yaitu korelasi indikator dalam konstruk yang sama) dalam uji validitas diskriminan, nilai yang diterima yaitu di bawah 1,00 atau 0,90 (Garson, 2016). Berdasarkan Tabel 4 Rasio Heterotrait-Monotrait (HTMT) menunjukkan bahwa semua rasio di bawah 0,90 , yang berarti bahwa melalui indikator HTMT, validitas diskriminan penelitian juga sudah baik.

Tabel 5. Uji Model Struktural

\begin{tabular}{rrr}
\hline & $R$ Square & Adjusted $R$ Square \\
\hline$P I$ & 0,555 & 0,543 \\
\hline
\end{tabular}

Berdasarkan hasil Tabel 5 Uji Model Struktural Adjusted R Square dari variabel yang mempengaruhi green product purchasing intention yang diuji dalam penelitian ini menunjukkan nilai sebesar 0,543 . Hal ini berarti bahwa sebanyak 54,3 $\%$ (> 50\%) variabel yang diteliti dapat menjelaskan variabel dependennya, sisanya sebanyak $45,7 \%$ di luar variabel penelitian. 
Tabel 6. Analisis Jalur

\begin{tabular}{lllr}
\hline & STDEV & $\begin{array}{c}\text { T } \\
\text { Statistik }\end{array}$ & P Value \\
\hline$A->P I$ & 0,085 & 3,305 & 0,001 \\
$S N->P I$ & 0,076 & 3,449 & 0,001 \\
$P B->P I$ & 0,074 & 2,020 & 0,044 \\
$E C->P I$ & 0,069 & 3,781 & 0,000 \\
\hline
\end{tabular}

Berdasarkan Tabel 6, hipotesis pertama yang menyatakan bahwa sikap mempunyai pengaruh positif terhadap intensi pembelian produk ramah lingkungan, diterima. Hal ini dibuktikan dengan $\mathrm{p}$ value $<0,05(0,001)$ dengan nilai STDEV 0,085 dan nilai T 3,305 yang menunjukkan hubungan positif. Hipotesis kedua yang menyatakan bahwa norma subjektif mempunyai pengaruh positif terhadap intensi pembelian produk ramah lingkungan. Hipotesis tersebut diterima, hal ini dibuktikan dengan $\mathrm{p}$ value $<0,05(0,001)$ demgan nilai STDEV 0,076 dengan nilai $\mathrm{T}$ 3,449 menunjukan adanya hubungan positif. Hipotesis ketiga yang menyatakan bahwa kontrol perilaku mempengaruhi pengaruh positif terhadap intensi pembelian produk ramah lingkungan. Hipotesis tersebut diterima, hal ini dibuktikan dengan $\mathrm{p}$ value < $0,05(0,044)$ dengan nilai STDEV 0,074 dan nilai $\mathrm{T}$ 2,020 menunjukkan adanya hubungan positif. Hipotesis keempat yang menyatakan bahwa kepedulian lingkungan mempunyai pengaruh kontribusi produk ramah lingkungan. Hipotesis tersebut diterima, hal ini dibuktikan dengan $\mathrm{p}$ value $<0,05(0,000)$ dengan niali STDEV 0,069 dengan nilai $T$ 3,781 yang menunjukkan hubungan positif. Sehingga dapat disimpulkan sikap, norma subjektif, kontrol perilaku, kepedulian lingkungan secara simultan berpengaruh positif terhadap intensi pembelian produk ramah lingkungan.

\section{Pengaruh Sikap terhadap Intensi Pembelian Produk Ramah Lingkungan}

Berdasarkan hasil penelitian, terdapat pengaruh positif sikap terhadap intensi pembelian produk ramah lingkungan. Hasil ini sesuai dengan hasil dari penelitian terdahulu Varah, et al., (2020) yang menyatakan bahwa sikap berpengaruh terhadap intensi perilaku pembelian produk hijau yang dilakukan pada konsumen berusia muda di India. Hasil dari penelitian Sun dan Wang (2019) yang menyatakan bahwa sikap produk hijau berpengaruh pada intensi pelanggan dalam pembelian produk hijau juga terbukti sesuai dengan hasil dari penelitian ini. Hasil dari penelitian Jacob, Putri, dan Sihombing (2020) yang menyatakan bahwa sikap berpengaruh pada intensi pembelian produk hijau juga sesuai dengan hasil penelitian ini. Dengan demikian, saat konsumen Generasi Z merasa yakin bahwa berbelanja produk ramah lingkungan merupakan hal yang positif maka akan semakin meningkatkan niat berbelanja mereka pada produk ramah lingkungan.

\section{Pengaruh Norma Subjektif terhadap Intensi Pembelian Produk Ramah Lingkungan}

Berdasarkan hasil penelitan, terdapat pengaruh positif norma subjektif terhadap intensi pembelian produk ramah lingkungan. Hasil penelitian ini juga sesuai dengan hasil penelitian yang telah dilakukan oleh Yadav dan Pathak (2016) yaitu adanya pengaruh positif dan signifikan antara norma subjektif dengan niat berbelanja produk ramah lingkungan. Penelitian lain yang mendukung yaitu Joshi dan Rahman (2015) yang menyatakan norma subjektif mempunyai pengaruh yang kuat terhadap intensi pembelian produk ramah lingkungan. Pembelian produk ramah lingkungan sangat dikaitkan dengan makna dan nilai sosial karena semua individu mempunyai berbagai kelompok sosial dan dengan adanya kelompok sosial tersebut dapat mempengaruhi intensi pembelian. Pada generasi Z, dengan adanya kelompok sosial yang mereka miliki dapat meningkatkan intensi pembelian produk ramah lingkungan.

\section{Pengaruh Kontrol Perilaku Terhadap Intensi Pembelian Produk Ramah Lingkungan}

Berdasarkan hasil penelitian yaitu terdapat pengaruh positif kontrol perilaku terhadap intensi pembelian produk ramah lingkungan. Hasil penelitian juga konsisten 
dengan penelitian yang telah dilakukan oleh Shukla (2019) menyatakan bahwa kontrol perilaku mempunyai pengaruh positif terhadap intensi produk ramah lingkungan pada generasi milenial di India. Penelitian lain yang mendukung yaitu Sun dan Wang (2019) menyatakan bahwa kontrol perilaku mempunyai pengaruh positif terhadap niat berbelanja produk ramah lingkungan pada generasi $\mathrm{X}$ dan $\mathrm{Y}$ di China. Pada saat seorang individu berbelanja produk ramah lingkungan terdapat beberapa faktor eksternal seperti waktu, harga, pengetahuan dan keterampilan. Pada generasi $\mathrm{Z}$ dapat meningkatkan niat berbelanja produk ramah lingkungan apabila mereka mempunyai cukup kemampuan dalam faktor waktu, harga, pengetahuan dan keterampilan.

\section{Pengaruh Kepedulian Lingkungan terhadap Intensi Pembelian Produk Ramah Lingkungan}

Berdasarkan hasil penelitian, terdapat kepedulian lingkungan terhadap intensi pembelian produk ramah lingkungan. Hasil penelitian ini selaras dengan hasil penelitian dari Paul, Modi dan Pate (2016) menyatakan bahwa adanya kepedulian lingkungan mempunyai pengaruh secara langsung terhadap niat berbelanja produk ramah lingkungan. Penelitian lain yang mendukung. Shukla (2019) menyatakan bahwa kepedulian mempunyai cukup pengaruh terhadap niat berbelanja produk ramah lingkungan pada milenial di India. Dengan demikian generasi $\mathrm{Z}$ mempunyai kepedulian tinggi terhadap lingkungan dan mereka mempunyai tanggung jawab secara individu untuk menjaga, melindungi dan memperbaiki lingkungannya.

Varibel sikap, norma subjektif, kontrol perilaku, dan kepedulian lingkungan yang digunakan dalam penelitian ini berpengaruh lebih dari 50\% $(54,3 \%)$ pada niat berbelanja produk ramah lingkungan. Selain itu berdasarkan hasil penelitian, semua hipotesis diterima dimana sikap, norma subjektif, kontrol perilaku, dan kepedulian lingkungan berpengaruh positif terhadap intensi pembelian produk ramah lingkungan
Implikasi dari hasil penelitian ini dapat menjadi suatu masukan strategi untuk para pendidik, pemerintah serta produsen agar selalu mengarahkan Generasi Z berbelanja lebih "hijau" untuk membentuk sikap dan peduli akan lingkungan. Peran serta pendidik serta pemerintah untuk mengajarkan perilaku konsumsi yang ramah lingkungan turut berpengaruh karena keterbatasan yang Generasi $\mathrm{Z}$ yang dimiliki saat ini, seperti pemahaman, dana, dan seterusnya. Jika strategi tersebut dilakukan secara bersamasama, diharapkan bahwa "campaign" baru bagi Generasi $\mathrm{Z}$ yang berdampak positif untuk lingkungan. Perubahan yang masif dan signifikan perlu diutamakan dan dikaji lebih dalam menilik tingginya tingkat kerusakan lingkungan di Indonesia. Para produsen khususnya menyasar kalangan generasi $\mathrm{Z}$ untuk membuat produk yang ramah lingkungan, berdasarkan penelitian ini generasi $\mathrm{Z}$ mempunyai keinginan berbelanja produk ramah lingkungan dikarenakan mempunyai tanggungjawab sebagai generasi muda untuk menjaga dan memperbaiki lingkungannya. Penelitian yang akan datang diharapkan untuk dapat memasukkan faktor ekuitas merek maupun nilai etis perusahaan dalam menjelaskan tentang niat berbelanja produk ramah lingkungan.

\section{Kesimpulan}

Penelitian terkait niat berbelanja produk ramah lingkungan terhadap generasi $\mathrm{Z}$ sangat menarik dan penting untuk dianalisa terutama pada masa sekarang ini, dimana banyak ditemukan degradasi lingkungan. Hal ini dikarenakan gaya hidup yang dipilih dan dicerminkan dalam intensi pembelian mereka turut membentuk perbaikan lingkungan hidup atau malahan memperburuk. Penelitian ini berupaya untuk menjelaskan intensi pembelian produk hijau (ramah lingkungan) dari modifikasi faktorfaktor dalam Theory of Planned Behavior, yaitu attitude, subjective norm, dan perceived behavioral control serta satu variabel modifikasi environmental concern. Berdasarkan hasil penelitian, semua hipotesis diterima dimana sikap, norma subjektif, 
kontrol perilaku, dan kepedulian lingkungan berpengaruh positif terhadap intensi pembelian produk ramah lingkungan

\section{DAFTAR PUSTAKA}

Ajzen, I. (1991). The theory of planned behavior. Organizational Behavior and Human Decision Processes, 50(2), 179211. https://doi.org/10.1016/07495978(91)90020-T

Ajzen, I. (2012). The theory of planned behavior. Lange, Krunglanski \& Higgins (Eds). Handbook of Theories of Social Psychology: London, UK: SAGE, I(July), 438-459. https://doi.org/10.4135/9781446249215. n22

Chaudhary, R., \& Bisai, S. (2018). Factors influencing green purchase behavior of millennials in India. Management of Environmental Quality: An International Journal, 29(5), 798-812. https://doi.org/10.1108/MEQ-02-20180023

Fornell, C., \& Larcker, D. F. (1981). SEM with Unobservable Variables and Measurement Error: Algebra and Statistics. Journal of Marketing Research, 18, 1-16.

Garson, G. D. (2016). Partial Least Squares: Regression \& Structural Equation Models.

Hair, J. F., Sarstedt, M., Ringle, C. M., \& Mena, J. A. (2012). An assessment of the use of partial least squares structural equation modeling in marketing research. Journal of the Academy of Marketing Science, 40(3), 414-433. https://doi.org/10.1007/s11747-0110261-6

Haryono, S. (2016). Metode SEM Untuk Penelitian Manajemen dengan AMOS LISREL dan PLS. Badan Penerbit PT. Intermedia Personalia Utama.

Jacob, M. R., Putri, Y. W., \& Sihombing, S. O. (2020). Predicting green product purchase: Applying a CognitiveAffective-Behavior hierarchy. Jurnal Siasat Bisnis, 24(2), 87-113. https://doi.org/10.20885/jsb.vol24.iss2.a rt1

Jaiswal, D., \& Kant, R. (2018). Green purchasing behaviour: A conceptual framework and empirical investigation of Indian consumers. Journal of Retailing and Consumer Services, 41, 60-69.

https://doi.org/10.1016/j.jretconser.2017 .11 .008

Joshi, Y., \& Rahman, Z. (2015). Factors Affecting Green Purchase Behaviour and Future Research Directions. In International Strategic Management Review, 3 https://doi.org/10.1016/j.ism.2015.04.00 1

Lee, K. (2008). Opportunities for green marketing: Young consumers. Marketing Intelligence and Planning, 26(6), 573-586. https://doi.org/10.1108/0263450081090 2839

Nekmahmud, M., \& Fekete-Farkas, M. (2020). Why not green marketing? Determinates of consumers' intention to green purchase decision in a new developing nation. Sustainability (Switzerland), 12(19), 1-31. https://doi.org/10.3390/su12197880

Nguyen, Y. T. H., \& Nguyen, H. V. (2021). An alternative view of the millennial green product purchase: the roles of online product review and self-image congruence. Asia Pacific Journal of Marketing and Logistics, 33(1), 231249. https://doi.org/10.1108/APJML10-2019-0612

Noor, et al. (2017). Determinants of generation $\mathrm{Z}$ green purchase decision: $\mathrm{A}$ SEM-PLS approach. International Journal of Advanced and Applied Sciences, 4(11), 143-147. https://doi.org/10.21833/ijaas.2017.011. 023

Noor, M. N. M., Jumain, R. S. A., Yusof, A., Ahmat, M. A. H., \& Kamaruzaman, I. F. (2017). Determinants of generation Z green purchase decision: A SEM-PLS approach. International Journal of Advanced and Applied Sciences, 4(11), 
143-147.

https://doi.org/10.21833/ijaas.2017.011. 023

Paul, J., Modi, A., \& Patel, J. (2016). Predicting green product consumption using theory of planned behavior and reasoned action. Journal of Retailing and Consumer Services, 29, 123-134. https://doi.org/10.1016/j.jretconser.2015 .11 .006

Prayoga, I. M. S., Adiyadnya, M. S. P., \& Putra, B. N. K. (2020). Green Awareness Effect on Consumers' Purchasing Decision. Asia Pacific Management and Business Application, 008(03), 199-208. https://doi.org/10.21776/ub.apmba.2020 .008.03.4

Shukla, S. (2019). A Study on Millennial Purchase Intention of Green Products in India: Applying Extended Theory of Planned Behavior Model. Journal of Asia-Pacific Business, 20(4), 322-350. https://doi.org/10.1080/10599231.2019. 1684171

Stage, F. K., Carter, H. C., \& Nora, A. (2004). Path analysis: An introduction and analysis of a decade of research. Journal of Educational Research, 98(1), 5-13.

https://doi.org/10.3200/JOER.98.1.5-13

Sugiyono. (2010). Statistika Untuk Penelitian. Bandung: Alfabeta.

Sun, Y., \& Wang, S. (2019). Understanding consumers' intentions to purchase green products in the social media marketing context. Asia Pacific Journal of Marketing and Logistics, 32(4), 860878. https://doi.org/10.1108/APJML03-2019-0178

Varah, F., Mahongnao, M., Pani, B., \& Khamrang, S. (2020). Exploring young consumers' intention toward green products: applying an extended theory of planned behavior. Environment, Development and Sustainability, 23, 9181-9195.

https://doi.org/10.1007/s10668-02001018-Z

Yadav, R., \& Pathak, G. S. (2016). Young consumers' intention towards buying green products in a developing nation: Extending the theory of planned behavior. Journal of Cleaner Production, 135, 732-739. https://doi.org/10.1016/j.jclepro.2016.0 6.120 